\title{
Towards Cultural Resistance in a Postcolonial Context \\ Translating Culture-loaded Tourist Texts in Shantou
}

\author{
Mingming YUAN* \\ English Language Centre, Shantou University, 243 Daxue Road, Shantou, Guangdong, China
}

Corresponding Author: Mingming YUAN, E-mail: mmyuan@stu.edu.cn

The research is financed by Guangdong Tertiary Innovative Talents Project. No. 2015WQNCX032 and Shantou University Fund for Research in Liberal Arts No. SR15002.

\author{
ARTICLE INFO \\ Article history \\ Received: November 18, 2017 \\ Accepted: January 11, 2018 \\ Published: March 01, 2018 \\ Volume: 7 Issue: 2 \\ Advance access: February 2018 \\ Conflicts of interest: None \\ Funding: None
}

\begin{abstract}
As tourist texts serve the triple function of providing information, expressing feelings and appealing to the reader, they contain both content-oriented information and culture-bound information. Through an analysis of the English translations of the Eight Sights of Shantou, this paper investigates how content-oriented information and culture-bound information is dealt with differently in the target text. The paper calls for a "thick translation" of culture-loaded tourist texts so as to resist the global hegemony of the Anglophone culture, preserve cultural richness and promote cultural diversity.
\end{abstract}

Key words: Tourist Texts, Translation, Postcolonial Translation Theories, Thick Translation, Resistance

\section{INTRODUCTION}

This paper investigates the translation of tourist texts into English in a small coastal city in China-Shantou. First emerged as a fishing village during the Song Dynasty and then as a region in Chao Prefecture (Chaozhou), Shantou was opened as a free trading port for foreigners at the end of the Second Opium War (1856-1860). It is among one of the few cities in China with a history of semi-colonisation, the impact of which can still be observed in the city landscape. In 1981, as part of the open-door policy of China, Shantou was listed as a Special Economy Zone (SEZ). Into the twenty-first century, Shantou started to attract increasing economic, cultural and academic cooperation throughout the globe. As part of an endeavour to enhance the internationalisation of Shantou and promote the city globally, the municipal government initiated a series of translation projects, rendering various aspects of the city's linguistic landscape into English. Part of the endeavour was to setup an English website for the Eight Sights of Shantou, a selection of tourist attractions to showcase Shantou's natural and cultural heritage.

This paper focuses on the English translations of the names of the Eight Sights. As a type of tourist text, the names of the Eight Sights contain both information about the site and reference to Chinese culture. The paper shall analyse the translation strategies employed to render such information with relation to the perceived functions of tourist texts, aiming to explore whether differentiating methods are used to represent different types of information in the source text, and what implications this may have for translation in a postcolonial context.

\section{LITERATURE BACKGROUND}

\section{Theoretical framework: the cultural approach to translation}

In the mid-1990s, the role the sociocultural context of the target culture plays in translation is increasing stressed by translation scholars. In the 1990 volume edited by Susan Bassnett and André Lefevere, Translation, History and Culture, translation is conceptualised as an act of "rewriting" subject to the influence of various factors in the target culture. The change of focus from a formalist linguistic phase to a culture-oriented approach is referred to as the "culture turn" (Bassnett \& Lefevere 1990, pp. 3-4) in translation studies. The volume has also approached translation from a postcolonial perspective, probing how geopolitical power relations between cultures influence the translation process.

In her essay The Politics of Translation, Gayatri Chakravorty Spivak (1992/2004) investigates the translation of Third World literatures into English, observing that the cultural elements unique to each literature are standardised in translation, leading to the elimination of the identify of less powerful countries. Tejaswini Niranjana's 1992 book 
Siting Translation: History, Post-structuralism and the Colonial Context takes a similar stance, arguing that translation reflects the asymmetrical power relations imposed by colonisation (Niranjana, 1992). From a similar perspective, Lawrence Venuti $(1995,1998)$ extends the issue to how the global hegemony of English influences translation between English and other languages. As Venuti sees it, the prevalence of transparent, smooth texts in translations from other languages into English is a sign of unequal cultural exchange. By making a foreign text as smooth and natural as if it were written in English, the culture that text bares is inevitably assimilated into the Anglophone culture, failing to realise one of the most important purposes of translation: promoting an equal cultural exchange and enhance cultural diversity. The cultural approach to translation studies forms the basic theoretical tenets of the present study, with translation conceptualised as a culture-oriented act under constant influence of various factors and constraints in the target culture context.

\section{The translation of tourist texts}

Katharina Reiss (1989) classifies the tourist text as a type of operative text, aiming to attract tourists' attention and invite patronage. Mary Snell-Hornby (1999) observes that tourist texts are both culture-bound and content-oriented: they are culture-bound in that the appeal to readers varies according to their cultural and personal background; they are content-oriented in that they provide essential information about tourist attractions. Kang Ning (2005) analysed the translation of tourist texts in China, arguing that tourist texts have vocative, informative and expressive functions. The vocative function is seen as the primary function of tourist texts, which aims to attract the reader's attention and to invite them to take action. The informative function serves to introduce scenic spots and to provide relevant information. The expressive function is related to the author's intention to express their feelings and to evoke compassion among the reader. Kang argues that in order to reproduce a functionally equivalence target text, various translation strategies (such as addition, deletion, replacement) should be used to duplicate the intended function of the source text.

Other researchers approach the translation of tourist texts from a culture-oriented perspective. He Sanning (2010) proposes that tourist texts have an aesthetic function; as an important bearer of cultural values, tourist texts are closely related to practices and traditions in the source culture. Following the theoretical framework of the Manipulation School (Lefevere, 1992), Zhang Baicheng (2012) conceptualises the translation of tourist texts as a form of rewriting, in which process the translator manipulates the source text to highlight cultural elements and to omit information that is irrelevant or tenebrous. Zhang Meifang (2012) analysed the translation of site names in Macao historical centre, observing that site names often have historical and cultural bearings, which are sometimes changed or altered in translation. For instance, "Ruins of St. Paul's" is translated as “大三巴 牌坊” (Dasanba Paifang, three big arch gates). Zhang found that while some names are translated with source-text orient- ed translation strategies, others are translated with target-text oriented translation strategies. She attributed the difference to the need of preserving both Chinese and Western cultures and to people's preference for names that are easy to remember and articulate.

\section{RESEARCH METHOD}

This paper analyses the translation of the Eight Sights of Shantou, an umbrella term for the eight most famous tourist attractions in the city. Historically, there were several versions of the Eight Sights, which were named respectively in 1928, 1939, 1991 and 2002. The present study focuses on the version in 2002, which is the most recent and the only version that is translated into English. The translations of the sight names are collected from the English website of Shantou municipal government.

Following Aixelá (1996)'s typology, the translator's treatment of culture-bound elements is classified into a group of strategies, listed according to the degree to which they preserve cultural elements in the source text: while strategies closer to the foreignisation axis are source-text oriented and tend to preserve the source culture; strategies closer to the domestication axis are target-text oriented, adapting source culture elements to suit the target culture.

Table 2 provides a summary of the Chinese names of the Eight Sights of Shantou along with their English translations. As the table indicates, there are two Chinese names for each sight: an official name in the form of a four-letter phrase following rhetorical patterns of Classical Chinese, and a common name offering a brief description of the sight. The official names of the Eight Sights were collectively chosen by a group of Chinese specialists, many of which contain archaic expressions alluding to classic Chinese poems. The common names are more reader-friendly and serve as an explanation of the nature, location or main attractions of the sight.

In the source text, the common names of the Eight Sight generally contain two elements: the proper name of the place and a descriptive name of the sight. In translation, most of these names are rendered with a combination of two strategies: preservation and linguistic translation. The place name is preserved with pinyin (the Chinese Phonetic Alphabet), whereas the descriptive name is translated according to its linguistic meaning.

E.g. 1

ST: 桑浦山风景区 (Sangpushan Fengjing Qu)

TT: Mount Sangpu Scenery Area

In example 1, for instance, the proper name of the mountain, “桑浦” (Sangpu), is preserved in pinyin, whereas “山” (shan) and “风景区” (fengjin qu) are respectively translated according to their linguistic meaning as "mount" and "scenery area."

E.g. 2

ST: 莲花峰风景区 (Lianhua Feng Fengjing Qu)

TT: Lianhua Peak (Lotus Peak)

Sometimes the proper name of the sight name can also have a descriptive meaning, in which case an additional translation is provided. In example 2 , in addition to trans- 
Table 1. Strategies for translating culture-bound elements (adapted from Aixelá [1996])

\begin{tabular}{ll}
\hline Translation strategy \\
$\begin{array}{ll}\text { Foreignisation } \\
\text { oriented) }\end{array}$ & $\begin{array}{l}\text { 1. Preservation: Keeping the culture-bound element in its present form } \\
\text { 2. Orthographic adaptation: Adapting the element to the writing system of the target culture } \\
\text { 3. Loanwords: Translating with existing phonemic or semantic loans }\end{array}$ \\
& 4. Literal translation: Word-for-word translation \\
& 5. Linguistic translation: Translating the linguistic denotation of the element \\
& 6. Extra-textual gloss: Providing additional explanation outside the text \\
7. Inter-textual gloss: Providing additional explanation as part of the text \\
8. Replacement: Replacing with a more familiar item \\
9. Universalisation: Replacing with an universally accepted item or concept \\
10. Localisation: Replacing with an item in the target culture \\
11. Deletion: Deleting the culture-bound element \\
12. Creation: Autonomous creation or addition \\
13. Mistranslation: Mispresenting the meaning of the culture-bound element \\
oriented)
\end{tabular}

Table 2. Eight Sights of shantou and their English translations

\begin{tabular}{|c|c|c|c|}
\hline $\begin{array}{l}\text { Source text: } \\
\text { Common name }\end{array}$ & $\begin{array}{l}\text { Target text: } \\
\text { Common name }\end{array}$ & $\begin{array}{l}\text { Source text: } \\
\text { Official name }\end{array}$ & $\begin{array}{l}\text { Target text: } \\
\text { Official name }\end{array}$ \\
\hline 桑浦山风景区 (Sangpu Shan Fengjing Qu) & Mount Sangpu Scenery Area & $\begin{array}{l}\text { 桑浦清辉 } \\
\text { (Shangpu Qinghui) }\end{array}$ & $\begin{array}{l}\text { Sangpu } \\
\text { Moonlight }\end{array}$ \\
\hline $\begin{array}{l}\text { 环汕头湾旅游圈 } \\
\text { (Huan Shantouwan Lvyou Quan) }\end{array}$ & Shantou Bay Tourist Area & $\begin{array}{l}\text { 海湾虹影 } \\
\text { (Haiwan Hongying) }\end{array}$ & $\begin{array}{l}\text { Rainbow over } \\
\text { the Bay }\end{array}$ \\
\hline 莲花峰风景区 (Lianhua Feng Fengjing Qu) & Lianhua Peak (Lotus Peak) & $\begin{array}{l}\text { 莲峰浩气 } \\
\text { (Lianfeng Haoqi) }\end{array}$ & $\begin{array}{l}\text { Upright Lotus } \\
\text { Peak }\end{array}$ \\
\hline $\begin{array}{l}\text { 中信高尔夫海滨度假村 (Zhongxin Gao'erfu } \\
\text { Haibin Dujiacun) }\end{array}$ & Zhongxin Golf and Resort & $\begin{array}{l}\text { 龙滩逸韵 } \\
\text { (Longtan Yiyun) }\end{array}$ & $\begin{array}{l}\text { Charming } \\
\text { Dragon Beach }\end{array}$ \\
\hline 中山公园 (Zhongshan Gongyuan) & Zhongshan Park & $\begin{array}{l}\text { 月苑莺声 } \\
\text { (Yueyuan Yingsheng) }\end{array}$ & $\begin{array}{l}\text { Nightingale in } \\
\text { Moonlight }\end{array}$ \\
\hline 陈慈黄故居 (Chen Cihong Guju) & Chen Cihong's Residence & $\begin{array}{l}\text { 黄院慧风 } \\
\text { (Hongyuan Huifeng) }\end{array}$ & $\begin{array}{l}\text { Nice Breeze } \\
\text { in Cihong's } \\
\text { Residence }\end{array}$ \\
\hline 礐石风景名胜区 (Queshi Fengjing Mingsheng Qu) & Queshi Scenery Area & $\begin{array}{l}\text { 礐石山光 } \\
\text { (Queshi Shanguang) }\end{array}$ & $\begin{array}{l}\text { Queshi Mountain } \\
\text { Scenery }\end{array}$ \\
\hline 南澳岛生态旅游 (Nan'ao Dao Shengtai Lvyou Qu) & Nan'ao Island Eco-Tourist Area & $\begin{array}{l}\text { 瀛南翠色 } \\
\text { (Yingnan Cuise) }\end{array}$ & $\begin{array}{l}\text { Jade in South } \\
\text { Sea }\end{array}$ \\
\hline
\end{tabular}

lating “莲花峰” (Lianhua Feng) as “Lianhua Peak,” the descriptive meaning of “莲花” (lianhua, lotus) is also supplied in brackets. Unlike the first example, “风景区” (fengjing qu, scenic spot) is omitted in translation, probably because the meaning is implied in the context.

E.g. 3

ST: 瀛南翠色 (Yingnan Cuise)

TT: Jade in South Sea

As discussed previously, the official names of the Eight Sights often contain allusions to classic Chinese literature. As such, these names serve an expressive function, aiming to showcase the aesthetic beauty of Chinese and the rich culture behind the attraction. In example 3, “渂” (ying) is the archaic Chinese expression for "sea”, while “南” (nan) means “south.” Put together, “瀛南” (yinghan) is the traditional name of Nan'ao Island during the Liang Dynasty (502-587).
By relating Nan'ao Island to its traditional name, the source text reminds the reader of the rich historical background behind the attraction. However, such information is not duly reflected in translation. In the target text, the phrase is simply translated literally as "South Sea." Although "Jade in South Sea" is geographically accurate (the island is indeed located in South China Sea), it did not fully represent the cultural and historical information in the source text.

E.g. 4

ST: 桑浦清辉 (Shangpu Qinghui)

TT: Sangpu Moonlight

In example 4, “桑浦” (Sangpu) is the proper name of a mountain in the northwest part of Shantou. The phrase " 清晖” (xinghui, clear light) derives from the work of landscape poet Xie Lingyun (385-433), “昏旦变气候, 山水含 清晖” (hundan bian qihou, shanshui han qinghui), which 
roughly means "the weather changes from day to night; the mountains and the water shine in bright light." The phrase had since become an allusion for "landscape" or "view" in Classical Chinese. According to Huang Zaifa, leader of the specialist group in charge of the selection and naming of the Eight Sights, the phrase “清晖” (xinghui) was selected to pay tribute to Xie's poetry and to reflect the tranquil beauty of Sangpu Mountain (Lin \& Shao, 2002). In the target text, “清晖” (xinghui) is interpreted literally as “clear light,” and mistranslated as "moonlight," failing to represent the allusion and to acknowledge the literary tradition behind the name.

\section{E.g. 5}

\section{ST: 曺院慧风 (Hongyuan Huifeng)}

TT: Nice Breeze in Cihong's Residence

Apart from allusions to classic Chinese literature, the official names of the Eight Sights also use institutionalised metaphors to enrich the discourse. In example 5, “賞院” (hongyuan, Hong's courtyard) refers to a residential museum build on the dwellings of Chen Ci'hong, a philanthropist and educationalist who has made great contributions to the modernisation process of Shantou. In the source text, “惠风” (huifeng, pleasant breeze) is an archaic expression in Classical Chinese, which is often used metaphorically to refer to acts of benevolence. In the source text, the word was chosen to honour Chen's philanthropic deeds (Lin \& Shao, 2002). In the target text, however, the metaphor is translated literally as "nice breeze." The intertextual connection between the metaphorical meaning of “惠风” (huifeng, pleasant breeze) and Chen's contributions as a philanthropist is lost in translation.

\section{E.g. 6}

\section{ST: 月苑荣声 (Yueyuan Yingsheng)}

TT: Nightingale in Moonlight

Sometimes the official names of the sights contain geographical references, which is not always duly represented in translation. In example 6, “月苑” (Yueyuan, Moon Gardens) refers to Zhongshan Park, a local botanic and zoological park first built in 1926. The park was named after a river, “ 月眉河” (Yuemei He, Moon Crescent River), which curves around the park like a crescent moon. The rest part of the name, “莺声” (yingsheng, birdsong), comes from the Chinese idiom “莺歌燕舞” (ying ge yan wu, songbirds sing and swallows dance), a metonymy for the joys and beauty of nature in spring. In the target text, “月眉河” (Yuemei He, Moon Crescent River) is mistranslated as "moonlight," whereas " 茑” (ying, songbird) is replaced with "nightingale", creating a visual image quite different from the source text.

\section{E.g. 7}

ST: 龙滩逸韵 (Longtan Yiyun)

TT: Charming Dragon Beach

The source text may also contain phrases with a specifically designated meaning, in which case a thorough understanding of the text as well as the nature of the tourist attraction is needed to produce an appropriate translation. In example 7, “龙滩” (longtan, dragon beach) derives from the local name of the beach, “龙虎滩” (Longhu Tan, Dragon and Tiger Beach). The other part of the name, “逸韵” (yihun, leisure time), refers to the recreational resources on the beach: the golf court, the swimming pool and the ocean spa (Lin \& Shao, 2002). The source text intends to perform a vocative function, inviting the reader to take action and pay patronage. In the target text, a fairly generic adjective, "charming", is used to describe the beach, failing to highlight its main attraction as a holiday resort. To duplicate the intended vocative function of the source text, the name could be translated as "Dragon Beach Golf and Ocean Spa."

\section{DISCUSSION}

Information in tourist texts, as discussed previously, can be classified into two types: culture-bound and contend-oriented (Snell-Hornby, 1999). This paper has discussed the translation of two types of names of the Eight Sights: the common names and the official names. The common names often contain content-oriented information, as their main function is to provide relevant information about the sight to the reader. In translation, the informative function is realised by translating the linguistic meaning of the source text. The official names, on the other hand, tend to provide culture-bound information. By using archaic expressions and literary allusions, they invite the reader of the source text to revisit the shared literary tradition, culture and local history, and to appreciate the aesthetic beauty of the discourse. As such, they serve important expressive functions. However, as Snell-Hornby (1999) points out, culture-bound information is also culturally dependent. The effect it has on the reader depends on their cultural and personal background. For readers who are unfamiliar with Classic Chinese literature and the local history of Shantou, it is quite challenging to represent the culture-bound information in the Eight Sights. Therefore, the culture-bound information in the source text is often changed into content-oriented information. Literary allusions and institutionalised literary metaphors are either replaced directly with their reference, or translated according to the literal meaning of the text. Although the informative function is preserved, the expressive function is lost in translation.

One way to compromise the loss of culture-bound information in translation is to opt for target-text oriented domesticating strategies. For instance, a culture-bound element in the source text could be replaced with another element in the target culture. Instead of translating “清晖” (qinghui) as "landscape" or "view," the translator could use a literary allusion in Anglophone culture with a similar meaning, recreating the allusion in the target text. While this strategy represents the rhetorical feature of the source text and may enhance the expressive function of the target text, it undermines the very motive behind translating tourist texts: to spread and promote local cultural heritage. As discussed before, in the postcolonial discourse, an important agenda for translation activities is to resist the global hegemony of the Anglophone culture (Venuti, 1995). If elements pertaining to the local culture are replaced with Anglophone elements, the translation would risk submitting to the ethnocentricity of the Anglophone culture, failing to promote cultural diversity and facilitate a balanced cultural exchange. 
The other option to compromise the loss of culture-bound information is to use source-text oriented translation tactics, a frequently used strategy being providing relevant cultural information through intra- or extra-textural gloss. Kwame Anthony Appiah proposed the notion of "thick translation," a translation "that seeks with its annotations and its accompanying glosses to locate the text in a rich cultural and linguistic context" (1993, p.817). Hermans argues that thick translation can serve as a critique of contemporary translation, calling attention to "the complex entanglements of concepts and practices of translation in their environment and history" (2003, p.386). Without suggesting that all tourist texts should be submerged in various forms of glosses, annotations and explanations, it would be useful to provide some background information for target text readers, so that they can have access to the shared knowledge of the source text readers. For the Eight Sights of Shantou, in addition to providing English translations of the names, it would be workable to add, either on the website or in tourist brochures and pamphlets, a paragraph explaining the story behind the names, providing information about the literary traditions, discursive features, historical background and geographical references behind these names. In this way, readers who are interested can gain more knowledge about the source culture, have a fuller understanding of the rhetorical and discursive features of these names, and better appreciate the expressive function they intend to perform.

\section{CONCLUSION}

This paper aims to explore whether differentiating methods are used to render different types of information in tourist texts, and what implications this may have for translation in a postcolonial context. Through an analysis of the English translations of the Eight Sights of Shantou, it is found that the common names of the Eight Sights are primarily content-oriented and are translated according to their linguistic meaning. Most of the official names, on the other hand, contain culture-bound information with reference to classic Chinese poems and institutionalised metaphors. As such, they mainly serve the expressive function, inviting the reader to appreciate the aesthetic beauty of the discourse. Due to the difficulty of representing these discursive features in translation, culture-bound information in the source text is often changed into content-oriented information in the target text. Although the contents in the official names are preserved, the expressive function is not duly represented in translation. In order to promote a balanced cultural exchange in translation, the paper argues against using domesticating translation strategies to render culture-bound information. Instead, it is proposed that culture-loaded site names could be rendered with the method of "thick translation", providing relevant background information in the form of notes, annotations and glosses, in the hope that the expressive function can be actively constructed by the reader in the reading process.

\section{REFERENCES}

Aixelá, J. F. (1996). Culture-Specific Items in translation. In R. Ávarez, \& M. C. África (Eds.), Translation, power, supervision (pp.52-78). Clevedon: Multilingual Matters. Appiah, K. A. (1993). Thick Translation. Calloo, 1993 (4), 801-819.

Bassnett, S., \& Lefevere, A. (Eds.). (1990). Translation, history and culture. London: Pinter.

He S. (2010). Lost and found in translating tourist texts: Domesticating, foreignising or neutralising approach. The Journal of Specialised Translation, 13, 124-137.

Hermans, T. (2003). Cross-cultural translation studies as thick translation. Bulletin of SOAS, 66(3), 380-389.

Kang N. (2005). A functional approach to the translation of tourism texts. Chinese Translation Journal, 25 (3), 85-89.

Lefevere, A. (1992). Translation, rewriting and the manipulation of literary fame, London; New York: Routledge.

Niranjana, T. (1992). Sitting translation: History, post-structuralism, and the colonial context. Berkeley; Los Angeles: University of California Press.

Reiss, K. (1989). Text types, translation types and translation assessment. (A. Chesterman, Trans.). In A. Chesterman (Ed.), Readings in Translation Theory (pp.105-115). Helsinki: Oy Finn Lectura Ab. (Original work published 1977).

Lin L. \& Shao J. (2002, December 15). Shantou Bajing chulu beihou de gushi (The story behind the Eight Sights of Shantou). Shantou Evening News. Retrieved from http:// www.chaoren.org/mrft/doc detail.asp?sendid=119

Snell-Hornby, M. (1999). The ultimate confort: Word, text and the translation of tourist brochures. In G. Anderman \& M. Rogers (Eds.), Word, Text, Translation. Liber Amicorum for Peter Newmark (pp. 95-103). Clevedon: Multilingual Matters, 95-105.

Spivak, G. C. (1992/2004). The politics of translation. In L. Venuti (ed.), The translation studies reader, $\left(2^{\text {nd }}\right.$ ed., pp. 369-388). New York; London: Routledge.

Venuti, L. (1995). The translator's invisibility: A history of translation. New York: Routledge.

(1998). The scandals of translation: Towards an ethics of difference, London; New York: Routledge.

Zhang B. (2012). On Chinese-English translation of culture-loaded tourism publicities: A perspective of cultural manipulation theory. Theory and Practice in Language Studies, 2 (11), 2342-2348.

Zhang M. (2012). Reading different cultures through cultural translation: On the translation of site names in Macau Historic Centre. Babel, 58 (2), 205-219. 